\title{
YOUNG FORM OF THE RARE CORAL FISH, MALACANTHUS LATOVITTATUS (LACEPEDE) FROM TANABE BAY
}

$\operatorname{AUTHOR}(\mathrm{S})$ :

Araga, Chuichi

\section{CITATION:}

Araga, Chuichi. YOUNG FORM OF THE RARE CORAL FISH, MALACANTHUS LATOVITTATUS (LACEPEDE) FROM TANABE BAY. PUBLICATIONS OF THE SETO MARINE BIOLOGICAL LABORATORY 1969, 16(6): 405-410

\section{ISSUE DATE:}

1969-03-31

URL:

http://hdl.handle.net/2433/175560

RIGHT: 


\title{
YOUNG FORM OF THE RARE CORAL FISH, MALACANTHUS LATOVITTATUS (LACÉPÈDE) FROM TANABE BAY ${ }^{1)}$
}

\author{
Chûtchi ARAGA \\ The aquarium, Seto Marine Biological Laboratory
}

With 2 Text-figures and 1 Table

Malacanthus latovittatus (LAGÉPÈDE), one of the very beautiful coral fish, is found rather rarely in the Japanese waters and thus appreciated highly for the aquarium exhibition. So far as I am aware, no specimen of its young stage has hitherto been reported. The first specimen of the young of this fish was collected in August of 1963 by SCUBA divers of the Suma Aquarium of Kobe City who thought then it might be a distinct wrasse referable to the genus Labroides. It was kept alive in a small tank for about three months, but unfortunately, it was so heavily damaged by a crab in the same tank just after its death that no confirmation of the juvenile characters was made at that time.

The second specimen was obtained by myself in a SGUBA dive in the autumn of 1967 and kept alive for about four months in a small recirculating tank. Sorry again, but the fish was preserved and left without being identified after it died. In last summer, we had for the first time an adult live individual of this fish in the laboratory aquarium and found that the behaviour of this adult fish was quite similar to those recorded on the above-mentioned unidentified young fish. Then, examining closely the preserved specimen of the young form, it was confirmed that the specimen was to be identified as a young of Malacanthus latovittatus for the following characters; elongate body, pointed snout, large mouth, counts of respective fin rays, and long base of dorsal and anal fins. In this paper the characteristic features and fresh colouration of this young fish are given together with its ecological notes comparing them with those of the adult.

Before going further, I wish to express my sincere gratitude and mourning to the late Prof. Kiyomatsu Matsubara who had kindly helped me greatly in the course of my ichthyological studies, but regrettably died of heart disease on December 12, 1968 , and this short paper is dedicated to the memory of the late Prof. Matsubara. I am very grateful to the collecting members of the Suma Aquarium for their kindness in offering me the very important specimen. I also thank to Prof. $H$.

1) Contributions from the Seto Marine Biological Laboratory, No. 507.

Publ. Seto Mar. Biol. Lab., XVI (6), 405-410, 1969. (Article 32) 


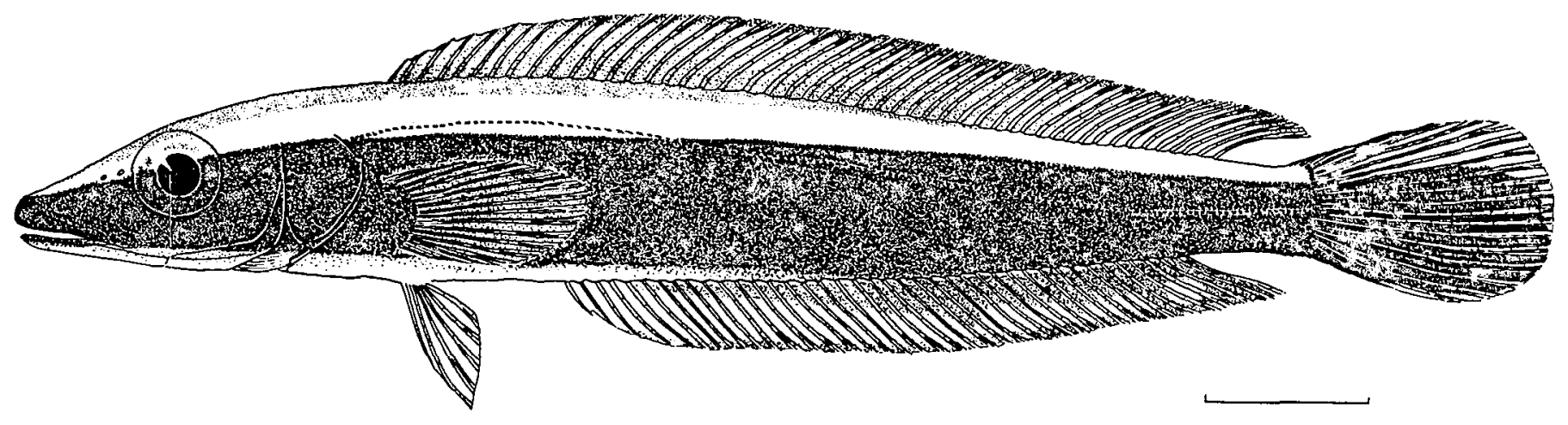

Text-figure 1. Lateral aspect of the juvenile of Malacanthus latovittatus (LACÉPÈDE). Scales are omitted to show the colour pattern clearly. The scale shows $10 \mathrm{~mm}$. 


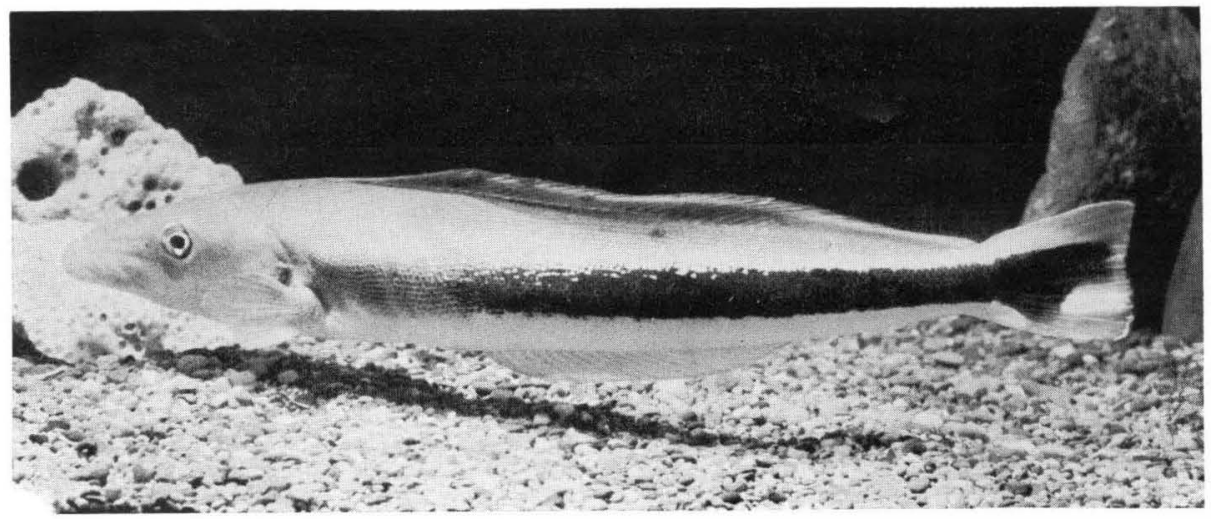

Text-figure 2. Malacanthus latovittatus (LACÉPÈDE), a $419 \mathrm{~mm}$ long adult swimming in aquarium.

Utinomi and Dr. T. Tokioka of the Seto Marine Biological Laboratory for their kindness in reading the manuscript.

\section{Malacanthus latovittatus (LACÉPÈDE)}

\section{(Japanese name: Kitsune-amadai)}

A single specimen, about $60 \mathrm{~mm}$ in standard length, collected from the shallow water near the laboratory on August 3, 1963, and another specimen, $79 \mathrm{~mm}$ in standard length, collected from the same place on October 21, 1967, were studied. The former was injured heavily so that the following measurements were made on the latter which was also somewhat damaged by parasitic bacteria while it was kept alive in the tank; and all of its caudal rays were lost but hypural bones remained completely. The caudal part of Text-figure 1 was drawn on the former specimen and the colour slides taken just after it was captured. One adult individual, $370 \mathrm{~mm}$ in standard length, collected from the Okinawa Islands in August 1968, was studied additionally. All the measurements on this adult fish exhibited at our laboratoty aquarium were carried out under anaesthetization with $0.01 \%$ MS-222.

Dorsal IV-45 (43 in smaller specimen); anal I-40 (39 in smaller specimen); pectoral $\mathrm{v}+12$; pelvic I-5; scales on lateral line more than 120 . These counts agree well with those of the adult. Proportional measurements are given in Table 1 in comparison with those of the adult.

Head and body elongate and compressed (head and anterior part of trunk subcylindrical*); snout not so produced, its length nearly equal to eye diameter (much produced, about 2.5 times as long as eye); dorsal profile from tip of snout to interorbital region straight, convex slightly from interorbital to origin of dorsal, gently arched on anterior dorsal base, and then nearly straight to caudal peduncle;

* Adult characters differing from those of the young are shown in parentheses. 
Table 1. Proportional measurements of both young and adult fish of Malacanthus latovittatus (in $\mathrm{mm}$ ).

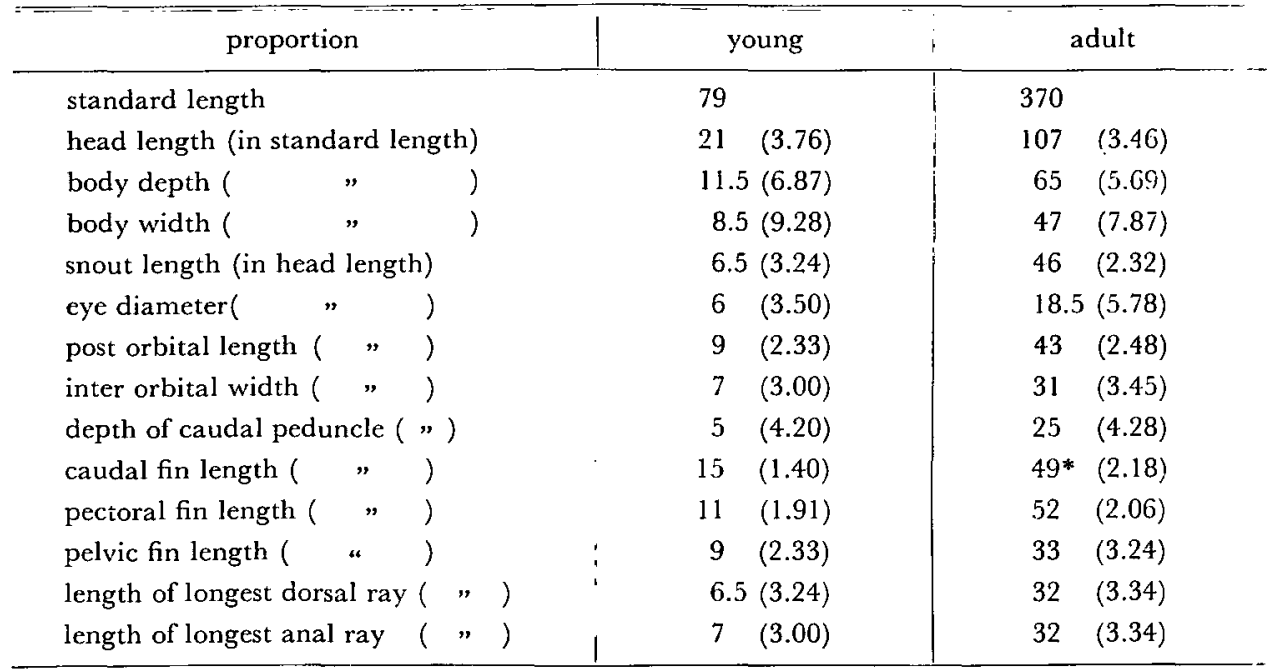

*: This caudal fin length might be shorter than natural size, as this individual was seemingly devoid of the ray tips of caudal fin when it was caught.

ventral outline from isthmus to caudal peduncle nearly straight; mouth large, nearly horizontal, posterior edge of maxillary almost reaches just below the frontal margin of eye (much shorter and fall far off eye); eye very large (rather small); interorbital region flat (convex), its width a little longer than eye diameter(1.7 times as long as eye); opercle with a sharp triangular spine on its hind margin (the spine stronger and much more produced); scales on head and body very small and finely ctenoid; dorsal fin low, the spines and rays all flexible, the rays of middle part longest; anal fin also low, the longest ray in anterior one third of the fin; caudal rounded distally (subtruncate with some undulation); pectroral fin oval, its central ray longest (pointed distally); pelvics very close together, the second ray longest, ending to a sharp point.

In life, body with a broad jet black band, extending from tip of snout, covering lower two third of eye, to caudal margin (narrower than in young, extending from behind pectoral fin to caudal fin where it branches downword, forming a white square on the posterior lower part of the fin); another bluish gray band runs from snout through the nape, covering anterior three quarters of dorsal fin base and tapering to a point; the longitudianl area between these two lengthwise bands pure white, sometimes faintly bluish; lower part of head and belly similarly white (head and back violet blue or grayish blue with slender vermiculated dark longitudilal lines, lower part of trunk bluish white); caudal fin jet black with a pale trianguler part and a white band of a considerable width on its upper part, lower margin white (upper part of caudal blue); dorsal fin dusky, paler posteriorly (greenish gray basally, 
paler distally): anal fin black basally, pale distally with blackish line near its margin (pale grayish); pectoral and pelvic fins pale (pectoral bluish, pelvics white).

After one year preservation, the jet black band on the body is faded somewhat into brownish; the pure white parts of back and belly have become dusky; the snout uniformly blackish exept for white chin; the upper part and the lower margin of caudal, pectoral and pelvics pale whitish; the anal base is pale.

The youngs of both Malacanthus latovittatus and the cleanning wrasse, Labroides dimidiatus (QUOY \& GAIMARD), are very similar to each other in general shape and colour pattern. Both fish have a jet black lengthwise broad band which occupies most part of body. The fish here described inhabited on the gravel floor, about five meters deep, between rocky reefs about 400 meters off northern beach of the laboratory, where the cleanning wrasse are found commonly. When I observed it first at a distance, $I$ wondered if it might be a large individual of $L$. dimidiatus retaining its juvenile colour pattern for some reason. The young of $L$. dimidiatus was formerly treated as a separate species, L. caeruleo-lineatus FowLer, but this was corrected by J. E. Randall in 1958 . Not only the colour pattern of the body, M. latovittatus does never fear divers and approaches them fairly close as $L$. dimidiatus does. According to Randall (1960) and Okuno (1966), L. dimidiatus is never avoided even by small fishes because of its special feeding habit of removing crustacean ectoparasites from other fishes. For this reason, the petroscirtine blenny, Aspidontus taeniatus QuoY \& GAIMARD, the mimic of $L$. dimidiatus, can easily approaches bait fishes making a pretense of $L$. dimidiatus. This may be applicable to the case of the predaceous young of $M$. latovittatus, which was fed regularly on small pieces of the clam in the aquarium, but sometimes on living small shrimps or fishes.

The remarkable resemblance between $M$. latovittatus and $L$. dimidiatus, phylogenetically quite separated from each other, presents possibly another case of mimicry, although $M$. latovittatus is inferior to $A$. taeniatus as the mimic of $L$. dimidiatus for the following reasons: The body form of $M$. latovittatus is slenderer than that of the model. $M$. latovittatus swims mainly with caudal fin, while the blenny swims with pectoral fins like wrasses. The blenny will often tear off pieces from other fishes' fins for food, but $M$. latovittatus never do this.

The fish collected in 1968 was kept alive in a 130 litter tank together with about fifteen small coral fishes, there it showed an interesting refuge making habit. It carried out sand grains with its mouth from under a dead massive coral placed in the tank. After the space under the coral reached the size nearly to hold its body length, the hole was then enlarged by sweeping sand grains away with a rapid action of its tail to the size large enough as its regular shelter. When it was surprised, or at night, the fish usually hid itself there.

The behaviours of adult fish kept in a 5.7 ton tank of the laboratory aquarium, the swimming mode and refuge making habit, are quite similar to those observed on the young. It makes a large hole under some rock on the sandy floor to use it as a 
shelter.

M. latorittatus has hitherto been known from the Okinawa Islands, and thus this is the first formal record of it from the coasts of Honshû Island.

\section{REFERENCES}

AoYAGI, H. 1948: Studies on coral fishes from the Riu-kiu Islands II, Families Synodontidae, Plotosidae, Pempheridae and others. Dobutsugaku Zassi (Zoological Magazine), 58 (3.4.5), pp. 48-50. (in Japanese)

Günther, A. C. 1876-81 : Andrew Garrett's Fishe der Südsee II. Jour. Mus. Godeffroy, 4, ii + 129 pp., pls. 84-140.

Herre, A. W. 1926: Four rare Philippine fishes. Philippine Jour. Sci., 31, (2), pp. 217-227, 1 fig., col. pl. 1.

Matsubara, K. 1955: Fish morphology and hieracy Part I. xii +799 pp., 289 figs. Ishizaki Shoten, Tokyo. (in Japanese)

Okuno, R. 1966: Peculiar habit of the cleanning wrasse, Labroides dimidiatus. Umi to Suizoku (The Sea and its Inhabitants), 7, (1), pp. 2-4, 9 figs. (in Japanese)

1966: Tales on the mimic of Labroides dimidialus. Ibid, 7, (2), pp. 2-4, 6 figs. (in Japanese)

Randall, J. E. 1958. A review of the labrid fish genus Labroides, with descriptions of two new species and notes on ecology. Pacific Science, 12, (4), pp. 327-346, 6 figs., col. pl. 1.

- and H. A. RANDAll 1960: Examples of mimicry and protective resemblance in tropical marine fishes. Bull. Mar. Sci. Gulf and Caribbean, 10(4), pp. 444-480, 15 figs.

Yasuda, F., 1966: Coral fishes illustrated in colour, their ecology and keeping. 59 pp. pls. 1-56. Asahi Press, Tokyo. (in Japanese) 